\title{
DEMOKRATISASI PENDIDIKAN ISLAM DALAM PANDANGAN KH. ABDUL WAHID HASYIM
}

\author{
Moh. Ismail \\ (Mahasiswa S-3 Pascasarjana UIN Sunan Ampel)
}

\begin{abstract}
Abstrak:
Perkembangan demokrasi dalam masyarakat menghendaki pendidikan yang sesuai dengan kebutuhan yang diinginkan oleh masyarakat terutama peserta didik. Pendidikan model lama yang menganggap peserta didik sebagai gentong yang diisi semuanya oleh pendidik atau yang oleh Paulo Friere dikatakan dengan sistem bank, perlu diganti dengan sistem pendidikan yang dapat mengembangkan kemampuan rakyat (people empowerment). Pada dasarnya, prinsip demokrasi itu memberi hak semua orang untuk mengambil keputusan dan memandang semua orang mempunyai posisi yang setara. Oleh karena itu, dalam demokrasi harus ada yang namanya kebebasan, harus ada penghormatan akan martabat orang lain, harus ada persamaan dan juga harus dapat menjamin tegaknya keadilan. Di Indonesia, KH. Abdul Wahid Hasyim berusaha menghadirkan konsep pendidikan Islam yang demokratis dalam rangka menjembatani permasalahan-permasalahan sosial terkini yang ada. Pendidikan Islam yang demokratis memberikan kesempatan kepada semua siswa untuk terlibat langsung dalam mengembangkan kemampuannya, sehingga siswa bisa menjadi manusia yang kritis dan kreatif.
\end{abstract}

Kata Kunci: Demokratisasi, Pendidikan Islam, KH. Abdul Wahid Hasyim. 


\begin{abstract}
:
The development of democratic society deserves education based upon societal needs, especially from students' need perspectives. Traditional education with -in Freire's terms- Banking education needs to be substituted by people empowerment education. Basically, democracy provides every individual the same rights to decide as everyone is in the equal position. Therefore, freedom is required in democracy as well as respects to others, and justice guarantee. Indonesia's KH. Abdul Wahid Hasyim attempts to display democratic Islamic education in purpose of solving contemporary social problems. The education provides opportunity to every students in directly involving activities for skill development; therefore the students are able to be more critical and creative.
\end{abstract}

Keywords: Democratization, Islamic Education, KH. Abdul Wahid Hasyim.

\title{
A. Pendahuluan
}

Dewasa ini, pendidikan terus-menerus dibangun dan dikembangkan agar menghasilkan generasi yang diharapkan. Dalam rangka menghasilkan peserta didik yang diharapkan dan unggul, proses pendidikan juga senantiasa dievaluasi dan diperbaiki. Zakiah Darajat mengemukakan tujuan mulia pendidikan Islam adalah menghasilkan manusia yang berguna bagi dirinya dan masyarakatnya serta senang dan gemar mengamalkan dan mengembangkan ajaran Islam dalam berhubungan dengan Allah dan sesamanya, dapat mengambil manfaat yang semakin meningkat dari alam semesta ini untuk kepentingan hidup di dunia dan akhirat. ${ }^{1}$ Marimba menjelaskan tujuan akhir pendidikan Islam ialah terbentuknya kepribadian Muslim. ${ }^{2}$

Pendidikan merupakan usaha sadar untuk mencapai tujuan tersebut. Pendidikan dapat diusahakan oleh manusia tetapi penilai tertinggi mengenai hasilnya adalah Tuhan Yang Maha Mengetahui. Tujuan pendidikan Islam identik dengan tujuan hidup setiap orang Muslim. Dalam al-Qur'an dinyatakan:

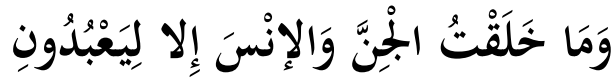

"Dan Aku tidak menciptakan jin dan manusia melainkan supaya mereka mengabdi kepada-Ku" (QS. Al-Dzariyat: 56).

\footnotetext{
1 Zakiah Darajat, Ilmu Pendidikan Islam (Bandung: Bumi Aksara, 2008), 29-30.

${ }^{2}$ Ahmad D. Marimba, Pengantar Filsafat Pendidikan Islam (Bandung: al-Maarif, 1962), 68.

Jurnal Pendidikan Agama Islam

Volume 4 Nomor 2 Nopember 2016

ISSN(p) 2089-1946\& ISSN(e) 2527-4511
}

Hal. 316 - 336 
Tujuan hidup manusia menurut agama Islam ialah untuk menjadi hamba Allah. Hamba Allah mengandung implikasi kepercayaan dan penyerahan diri kepada-Nya. Penyerahan diri berkait kelindan dengan memeluk agama Islam. ${ }^{3}$ Namun, mengapa bila dilihat insan-insan yang terdidik di negeri ini masih banyak perilakunya yang tidak sesuai dengan tujuan pendidikan Islam. Misalnya, tindak korupsi yang ternyata dilakukan oleh pajabat yang notabene orang-orang berpendidikan. Belum lagi tindak kekerasan yang akhir-akhir ini marak terjadi di negeri ini seperti anarkis, bahkan pembunuhan.

Pendidikan merupakan bimbingan atau pimpinan secara sadar oleh si pendidik terhadap perkembangan jasmani dan ruhani si terdidik menuju terbentuknya kepribadian yang utama. ${ }^{4}$ Zuhairini, sebagaimana yang dikutip oleh Hasan Basri $^{5}$ mengemukakan pendidikan adalah suatu aktivitas untuk mengembangkan seluruh aspek kepribadian manusia yang berjalan seumur hidup. Dengan kata lain, pendidikan tidak hanya berlangsung di dalam kelas, tetapi berlangsung pula di luar kelas. Pendidikan bukan bersifat formal, ${ }^{6}$ tetapi juga bersifat non formal. ${ }^{7}$

Secara substansial, pendidikan tidak sebatas pengembangan intelektual manusia, artinya tidak hanya meningkatkan kecerdasan, melainkan mengembangkan seluruh aspek kepribadian manusia. Makna pendidikan yang lebih hakiki lagi adalah pembinaan akhlak manusia guna memiliki kecerdasan membangun kebudayaan masyarakat yang lebih baik dan mampu meningkatkan kesejahteraan hidupnya. ${ }^{8}$

Dalam rangka membentuk manusia yang mulia dan bangsa yang bermartabat, upaya perbaikan harus segera dilakukan terutama dalam bidang pendidikan. Pendidikan model lama menganggap peserta didik sebagai gentong yang diisi semuanya oleh pendidik, atau yang oleh Paulo Friere dikatakan dengan sistem bank. Hal ini perlu diganti dengan sistem pendidikan yang dapat

3 Marimba, Pengantar Filsafat Pendidikan Islam, 46-48.

${ }^{4}$ Marimba, Pengantar Filsafat Pendidikan Islam, 19.

${ }^{5}$ Hasan Basri, Filsafat Pendidikan Islam (Bandung: Pustaka Setia, 2009), 54.

${ }^{6}$ Pendidikan Formal adalah jalur pendidikan yang terstruktur dan berjenjang yang terdiri atas pendidikan dasar, pendidikan menengah, dan pendidikan tinggi. Lihat Peraturan Pemerintah Republik Indonesia Nomor 19 Tahun 2005 Tentang Standar Nasional Pendidikan Bab I Ketentuan Umum Pasal 1 ayat (2).

7 Pendidikan non formal adalah jalur pendidikan di luar pendidikan formal yang dapat dilaksanakan secara terstruktur dan berjenjang. Lihat Peraturan Pemerintah Republik Indonesia Nomor 19 Tahun 2005 Tentang Standar Nasional Pendidikan Bab I Ketentuan Umum Pasal 1 ayat (3).

8 Moh. Yamin, Menggugat Pendidikan Indonesia (Yogyakarta: Ar-Ruzz Media, 2009), 15. 
mengembangkan kemampuan rakyat (empowering of people). ${ }^{9}$ Untuk itu, sekolah sebagai lembaga pendidikan (Islam) dituntut harus dapat mengerti dan memahami apa yang menjadi keinginan peserta didik, bukan memaksa mereka untuk tunduk dan patuh terhadap keinginan pendidik. Karena mendidik yang sesuai dengan keinginan peserta didik akan lebih berhasil ketimbang mendidik yang sesuai dengan keinginan pendidik.

Model pendidikan sebagaimana yang diharapkan tersebut di atas belum sepenuhnya terlaksana. Hal ini bisa dilihat dari proses pendidikan yang berlangsung. Selama ini, guru selalu menganggap bahwa dirinya adalah orang yang paling pintar, menang sendiri, paling berhak memperlakukan peserta didik sesuai dengan kemauannya. ${ }^{10}$

Lembaga-lembaga dan proses pendidikan berperan penting dalam membentuk perilaku masyarakat di sebuah negara. Begitu sebaliknya, lembagalembaga dan proses politik di suatu negara memberikan dampak besar pada karakteristik pendidikan sebuah negara. Hubungan tersebut adalah realitas empirik yang telah terjadi sejak awal perkembangan peradaban manusia dan menjadi perhatian para ilmuwan. ${ }^{11}$

Dalam konteks pendidikan di Indonesia memang tidak bisa terlepas dari knowledge and power (pengetahuan dan kuasa). Pengetahuan yang dapat diperoleh melalui pendidikan dan kuasa yang diemban oleh pemerintah untuk mengatur dan menentukan perkembangan peradaban bangsa Indonesia. Dengan kata lain transfer of knowledge and transfer of value menjadi tanggung jawab pemerintah untuk mensejahterakan rakyatnya.

Pemeritah memiliki tugas suci sebagai penentu kebijakan. Jika seseorang ingin megabdikan diri dengan maksimal maka jalan yang paling ideal adalah masuk pada struktural pemerintahan karena dalam hal ini seseorang bisa menjadi pengendali dan penentu kebijakan yang diorientasikan pada perkembangan serta kesejahteraan masyarakat. Tugas yang menjadi penting karena berimplikasi pada nilai kemanusiaan.

Nilai kemanusiaan ini bisa terciderai dengan ekspektasi sosial yang negatif dan ini dapat dilihat dari kecenderungan pada sikap anomali (ketidaknormalan), seperti: tawuran antar pelajar, hilangnya rasa solidaritas, kekerasan dan lain sebagainya. Dalam konteks yang lain, standar tingkah laku seseorang yang merupakan pengejawantahan dari nilai kemanusiaan dapat dilihat dari perspektif

${ }^{9}$ H.A.R.Tilaar, Paradigma Baru Pendidikan Nasional (Jakarta: Rineka Cipta, 2000), 145-146.

10 Ismail SM, Pendidikan Islam, Demokratisasi dan Masyarakat Madani (Yogyakarta : Pustaka Pelajar, 2000), 135.

11 M. Sirozi, Politik Pendidikan: Dinamika Hubungan antara Kepentingan Kekuasaan dan Praktik Penyelenggaraan Pendidikan (Jakarta: Raja Grafindo Persada, 2005), 1.

Jurnal Pendidikan Agama Islam

Volume 4 Nomor 2 Nopember 2016

ISSN(p) 2089-1946\& ISSN(e) 2527-4511

Hal. 318 - 336 
budaya, akal, dan ajaran yang itu memiliki produk aturan dan formulasi tersendiri serta efek yang ditimbulkan dari perbuatan buruk tersebut juga berbeda-beda.

Dalam dunia pendidikan, khususnya lembaga pendidikan yang digalakkan oleh pemerintah lebih bertendensi pada sistem kelas dan diorientasikan pada korporasi pendidikan. ${ }^{12}$ Seolah-olah lembaga pendidikan mengabaikan anak cerdas yang kurang mampu ( pintar-miskin ) daripada anak bodoh yang mampu (bodoh-kaya). Hal seperti ini yang menjadi kegelisahan rakyat Indonesia karena hak dalam pendidikan belum sepenuhnya bisa difasilitasi oleh pemerintah.

Dalam sejarah kemerdekaan Indonesia, setelah Hirosima dan Nagasaki pada 6 dan 9 Agustus 1945 di bom oleh Amerika Serikat, Jepang menyerah tanpa syarat kepada sekutu. Keadaan demikian berpengaruh kepada kekuatan balatentara Jepang di Indonesia. Momen demikian sangat kondusif bagi bangsa Indonesia untuk berjuang meraih kemerdekaan, dimana puncaknya adalah proklamasi kemerdekaan yang disampaikan oleh Ir. Soekarno dan Drs. Mohammad Hatta pada 17 Agustus 1945. Peristiwa ini mengakhiri masa pendudukan Jepang dan pada saat yang sama mengawali bangkitnya pendidikan nasional. ${ }^{13}$

Terkait dengan perkembangan pendidikan Islam di masa awal berdirinya negara Indonesia, tulisan ini berupaya untuk lebih mengerucutkan apa yang pernah ditulis oleh Heni Listiana tentang "Dinamika Politik Pendidikan Guru Agama Islam Pada Masa Orde Lama". Tulisan tersebut memaparkan bagaimana lebarnya jurang dikotomi antara pendidikan Islam dengan pendidikan umum, sehingga terbentuknya kementerian agama. Tulisan tersebut lebih meninjau pendidikan Islam dalam sudut pandang politis (politik pendidikan). ${ }^{14}$ Oleh karena itu, penulis menganggap penting untuk mengkaji pendidikan Islam dalam sudut pandang konsepsinya, yakni dari sisi demokrasi pendidikan Islam. Dalam pembahasan masalah demokrasi pendidikan, penulis mengangkat isu-isu konseptual dan teoritik yang mampu memberikan kerangkan pemahaman utuh. Sehingga bisa menunjuk kepada seperangkat tujuan, rencana atau usulan, program-program, keputusan-keputusan, serta undang-undang atau peraturan-

12 Korporasi pendidikan ialah prosesi pendidikan yang berusaha dimanfaatkan oleh para elit pengampu kebijakan dengan cara mencari keuntungan demi kebutuhan hidupnya. Korporasi pendidikan muncul akibat dari sistem kapitalisme di era modern ini.

${ }^{13}$ Abd. Rachman Assegaf, Politik Pendidikan Nasional: Pergeseran Kebijakan Pendidikan Agama Islam dari Praproklamasi ke Reformasi (Jogjakarta: Kurnia Kalam, 2005), 54.

14 Heni Listiana, "Dinamika Politik Pendidikan Guru Agama Islam Pada Masa Orde Lama" Jurnal Pendidikan Agama Islam (JPAI) FTK UIN Sunan Ampel Surabaya, Vol 1, No 2 (2013), 374-397. 
peraturan ${ }^{15}$ yang ini masih dalam rangkaian nuansa demokrasi pendidikan Islam menurut KH. Abdul Wachid Hasyim ${ }^{16}$. Sebelumnya, pemikiran KH. Abdul Wachid Hasyim telah dijabarkan oleh Rangga Sa'adillah S.A.P. dengan mengangkat pendidikan karakter. Tulisan yang mendeskripsikan nilai-nilai karakter dalam konsep pemikiran KH. Abdul Wachid Hasyim. ${ }^{17}$

Sementara, penulis lebih menguraikan bagaimana demokasi pendidikan merupakan hal yang urgen untuk dilakukan dalam rangka demokratisasi pendidikan itu sendiri. Pendidikan berbasis masyarakat secara politis merupakan perjuangan politik menuju transformasi sosial. Pendidikan berbasis masyarakat merupakan bagian dari agenda pendidikan kritis yang senantiasa berupaya membebaskan pendidikan dari belenggu kekuasaan. Manakala pendidikan telah terbebas dari dominasi dan hegemoni kekuasaan, itu berarti demokratisasi pendidikan dapat diwujudkan. Terlebih tokoh yang diambil dalam tulisan ini merupakan sosok yang sangat berpengaruh dan keberadaannya membawa dampak yang sangat besar dalam mengarahkan bangsa Indonesia menuju peradaban yang lebih mapan.

\section{B. Sketsa Pemikiran KH. Abdul Wahid Hasyim tentang Pendidikan Islam}

Secara substansal, pendidikan Islam ${ }^{18}$ berpadu dalam pendidikan ruhiyah, fikriyah dan amaliyah (aktivitas). Nilai Islam ditanamkan dalam individu membutuhkan tahpan-tahapan selanjutnya dikembangkan kepada pemberdayaan di segala sektor kehidupan manusia. Potensi yang dikembangkan kemudian

\footnotetext{
15 Mudjia Rahardjo, Pemikiran Kebijakan Pendidikan Kontemporer (Malang: UIN-MALIKI Press, 2010), 3.

${ }^{16} \mathrm{KH}$. Abdul Wahid Hasyim lahir di Jombang pada hari Jumat Legi 5 Rabiul Awal 1333 H/ 1 Juni 1914 M. Putra pertama Hadratus Syeikh K.H. M. Hasyim Asy'ari, pendiri jam'iyyah NU yang mempunyai silsilah sampai pada Sultan Brawijaya VI baik dari jalur ibu maupun Ayahnya. Lihat Aboebakar Atjeh, Sedjarah K.H.A. Wahid Hasjim dan Karangan Tersiar (Jakarta: Panitya Buku Peringatan Alm. K.H.A. Wahid Hasjim, 1957), 139-140.

17 Lihat Rangga Sa'adillah S.A.P, "Pendidikan Karakter menurut KH. Wahid Hasyim" Jurnal Pendidikan Agama Islam (JPAI) FTK UIN Sunan Ampel Surabaya Vol. 3. No. 2 (2015), 276303.

18 Pendidikan Islam memiliki 3 (tiga) tahapan kegiatan, yaitu: tilawah (membacakan ayat Allah), tazkiyah (mensucikan jiwa) dan ta'lim al kitab wa al sunnah (mengajarkan al kitab dan al hikmah). Pendidikan dapat merubah masyarakat jahiliyah menjadi umat terbaik disebabkan pendidikan mempunyai kelebihan. Pendidikan mempunyai ciri pembentukan pemahaman Islam yang utuh dan menyeluruh, pemeliharaan apa yang telah dipelajarinya, pengembangan atas ilmu yang diperolehnya dan agar tetap pada rel syariah. Hasil dari pendidikan Islam akan membentuk jiwa yang tenang, akal yang cerdas dan fisik yang kuat serta banyak beramal.
} 
diarahkan kepada pengaktualan potensi dengan memasuki berbagai bidang kehidupan.

Tujuan utama dalam pendidikan Islam adalah agar manusia memiliki gambaran tentang Islam yang jelas, utuh dan menyeluruh. Interaksi di dalam diri ini memberi pengaruh kepada penampilan, sikap, tingkah laku dan amalnya sehingga menghasilkan akhlaq yang baik. Akhlaq ini perlu dan harus dilatih melalui latihan membaca dan mengkaji al Qur'an, sholat malam, shoum (puasa) sunnah, berhubungan kepada keluarga dan masyarakat. Semakin sering ia melakukan latihan, maka semakin banyak amalnya dan semakin mudah ia melakukan kebajikan. Selain itu latihan akan menghantarkan dirinya memiliki kebiasaan yang akhirnya menjadi gaya hidup sehari-hari. Dengan demikian, hakikat cita-cita pendidikan Islam adalah melahirkan manusia-manusia beriman dan berpengetahuan, yang satu sama yang lainnya saling menunjang.

Sebagai seorang yang berasal dari pesantren, fokus utama pemikiran KH. Abdul Wahid Hasyim adalah peningkatan kualitas sumberdaya umat Islam. Upaya peningkatan kualitas tersebut menurut KH. Abdul Wahid Hasyim, dilakukan melalui pendidikan khususnya pesantren. Dari sini dapat dipahami, bahwa kualitas manusia muslim sangat ditentukan oleh tinggi rendahnya kualitas jasmani, rohani dan akal. Kesehatan jasmani dibuktikan dengan tiadanya gangguan fisik ketika berkatifitas. Sedangkan kesehatan rohani dibuktikan dengan keimanan dan ketakwaan kepada Allah yang kemudian diimplementasikan dalam kehidupan nyata.

Dalam fakta sejarah, K.H. Abdul Wahid Hasyim tidak pernah mengenyam pendidikan di bangku sekolah pemerintahan Hindia Belanda. Dia lebih banyak belajar secara autodidak. Selama belajar di Pondok Pesantren dan Madrasah, dia banyak mempelajari sendiri kitab-kitab dan buku berbahasa Arab. Dia mendalami syair-syair berbahasa Arab hingga hafal diluar kepala, selain itu juga menguasai maknanya dengan baik. ${ }^{19}$

K.H. Abdul Wahid Hasyim berotak cerdas. Saat berusia 5 tahun, ia belajar membaca al-Qur'an pada ayahnya setelah shalat maghrib dan zuhur, dia juga sekolah saat pagi di Madrasah Salafiah Tebuireng. Umur 7 tahun, ia mulai belajar kitab Fath al-Qarib, Minhajul Qawim pada ayahnya. Umur 12 tahun ia telah tamat dari Madrasah dan mulai mengajar adiknya (A. Karim Hasyim) kitab 'Izi saat malam. ${ }^{20}$

Sejak kecil minat membacanya sangat tinggi. Berbagai macam kitab berbahasa Arab ditelaahnya. Ia menggemari buku kesusasteraan Arab, khususnya

${ }^{19}$ Muhammad Rifai, Wahid Hasyim (Yogyakarta: Garasi, 2009), 23.

20 Atjeh, Sedjarah K.H.A. Wahid Hasjim dan Karangan Tersiar, 146. 
buku Diwan al-Syu'ara. ${ }^{21}$ Aboebakar menjelaskan metode belajar yang digunakan oleh Wahid Hasyim saat itu adalah muthala'ah dan membaca sendiri. Maka tidak sedikit hafalan-hafalan syair dalam bahasa Arabnya. Syair-syair tersebut dihimpun dan disusunnya dalam sebuah buku tebal. ${ }^{22}$

Sebagai seorang santri dan pendidik agama, fokus utama pemikiran $\mathrm{KH}$. Abdul Wahid Hasyim adalah peningkatan kualitas sumberdaya umat Islam. Upaya peningkatan kualitas tersebut oleh $\mathrm{KH}$. Abdul Wahid Hasyim dilakukan melalui pendidikan khususnya pesantren. Dari sini dapat dipahami, bahwa kualitas manusia muslim sangat ditentukan oleh tinggi rendahnya kualitas jasmani, ruhani dan akal. Kesehatan jasmani dibuktikan dengan tiadanya gangguan fisik ketika beraktifitas. Sedangkan kesehatan ruhani dibuktikan dengan keimanan dan ketakwaan kepada Allah yang kemudian diimplementasikan dalam kehidupan nyata. Disamping sehat jasmani dan ruhani, manusia muslim harus memiliki kualitas nalar (akal) yang senantiasa diasah sedemikian rupa sehingga mampu memberikan solusi yang tepat, adil dan sesuai dengan ajaran Islam. ${ }^{23}$

Mendudukkan para santri dalam posisi yang sejajar, atau bahkan bila mungkin lebih tinggi, dengan kelompok lain agaknya menjadi obsesi yang tumbuh sejak usia muda. Wahid Hasyim tidak ingin melihat santri berkedudukan rendah dalam pergaulan masyarakat. Karena itu, sepulangnya dari menimba ilmu pengetahuan (di Makkah), dia berkiprah secara langsung membina pondok pesantren (Tebuireng) asuhan ayahnya.

Pertama dia mencoba menerapkan model pendidikan klasikal dengan memadukan unsur ilmu agama dan ilmu-ilmu umum di pesantrennya. Ternyata uji coba tersebut dinilai berhasil. Karena itu dia dikenal sebagai perintis pendidikan klasikal dan pendidikan modern di dunia pesantren. Bagi pendidikan pondok pesantren Wahid Hasyim memberikan sumbangsih pemikirannya untuk melakukan perubahan. Banyak perubahan di dunia pesantren yang harus dilakukan. Mulai dari tujuan hingga metode pengajarannya.

Dalam mengadakan perubahan terhadap sistem pendidikan pesantren, Wahid Hasyim membuat perencanaan yang matang. Dia tidak ingin gerakan ini gagal di tengah jalan. Untuk itu, dia mengadakan langkah-langkah, di antaranya, menggambarkan tujuan dengan sejelas-jelasnya, menggambarkan cara mencapai

${ }^{21}$ Badiatul Roziqin, "KH. Abdul Wahid Hasyim Menjabat Menteri Agama Tiga Periode", dalam 101 Jejak Tokoh Islam Indonesia (Yogyakarta: e-Nusantara, 2009), 31.

22 Atjeh, Sedjarah K.H.A. Wahid Hasjim dan Karangan Tersiar, 146.

${ }^{23}$ Lihat Moch. Choirul Arif, K.H. Abdul Wahid Hasyim (1914-1953) Wawasan Keislaman dan Kebangsaan, (Tesis) (Surabaya: Program Pascasarjana IAIN Sunan Ampel Surabaya, 2003), 49-50. 
tujuan itu dan memberikan keyakinan dan cara, bahwa dengan sungguh-sungguh tujuan dapat dicapai. ${ }^{24}$

Pada awalnya, tujuan pendidikan Islam khususnya di lingkungan pesantren lebih berkonsentrasi pada urusan ukhrawiyah (akhirat), nyaris terlepas dari urusan duniawiyah (dunia). Oleh karena itu, pesantren didominasi oleh mata pelajaran yang berkaitan dengan fiqh, tasawuf, ritual-ritual sakral dan sebagainya. Meski tidak pernah mengenyam pendidikan modern, wawasan berfikir Wahid Hasyim dikenal cukup luas. Wawasan ini kemudian diaplikasikan dalam kegiatankegiatan yang bersifat sosial dan pendidikan. Berkembangnya pendidikan madrasah di Indonesia di awal abad ke-20, merupakan wujud dari upaya yang dilakukan oleh cendikiawan muslim, termasuk Wahid Hasyim, yang melihat bahwa lembaga pendidikan Islam (pesantren) dalam beberapa hal tidak lagi sesuai dengan tuntutan dan perkembangan zaman.

Apa yang dilakukan oleh Wahid Hasyim merupakan inovasi baru bagi kalangan pesantren. Pada saat itu, pelajaran umum masih dianggap tabu bagi kalangan pesantren karena identik dengan penjajah. Kebencian pesantren terhadap penjajah membuat pesantren mengharamkan semua yang berkaitan dengannya, seperti halnya memakai pantolan, dasi dan topi, dan dalam konteks luas pengetahuan umum.

Abdul Wahid Hasyim juga mencoba melakukan pembaruan untuk mengoreksi keefektifan metode yang digunakan di Pesantrennya (Tebuireng) yakni metode Bandongan dan Sorogan untuk diperbarui menggunakan metode tutorial. ${ }^{25}$ Wahid Hasyim mengusulkan untuk mengadopsi sistem tutorial, sebagai ganti dari metode bandongan. Menurutnya, metode bandongan sangat tidak efektif dalam mengembangkan inisiatif santri. Hal ini disebabkan oleh kondisi di mana metode bandongan diterapkan, santri datang hanya untuk mendengar, menulis dan menghafal pelajaran yang diberikan, tidak ada kesempatan bagi santri untuk mengajukan pertanyaan atau bahkan mendiskusikan pelajaran. Wahid Hasyim secara jelas menyimpulkan bahwa metode bandongan membuat santri pasif. ${ }^{26}$

${ }^{24}$ Atjeh, Sedjarah K.H.A. Wahid Hasjim dan Karangan Tersiar, 151.

25 Aboebakar Atjeh menjelaskan Bandongan dan Sorogan merupakan pendidikan cara kuno yang hanya menggunakan metode mendengar dan menggantungkan makna pada kitab fiqih Islam sudah mulai ditinjau kembali oleh Wahid Hasyim, apakah dengan cara demikian tidak terlalu banyak menyimpang (tidak efektif). Lihat Aboebakar Atjeh, Sedjarah K.H.A. Wahid Hasjim dan Karangan Tersiar, 151.

26 Sebenarnya mengenai usulan ini Hadratus Syaikh K.H. Hasyim Asy'ari tidak setuju karena perubahan radikal seperti itu akan menyebabkan kekacauan antara sesama pimpinan pesantren. Namun demikian, Hadratus Syaikh menyetujui usul K.H. Abdul Wahid Hasyim melalui pendirian Madrasah Nizamiyah tahun 1934 yang mengajarkan pengetahuan umum 
Abdul Wahid Hasyim, juga mencoba untuk mengoreksi harapan santri belajar di Pesantren. Dia mengusulkan agar kebanyakan santri yang datang di pesantren tidak berharap menjadi ulama. Oleh karena itu, mereka tidak perlu menghabiskan waktu bertahun-tahun dalam mengakumulasi ilmu agama melalui teks-teks Arab. Mereka dapat memperoleh ilmu agama dari buku-buku yang ditulis dengan huruf latin, dan menghabiskan sisa waktunya untuk mempelajari berbagai ilmu pengetahuan dibarengi kemampuan menguasai keterampilan yang berguna secara langsung di tengah masyarakat di mana mereka berada. Hanya sebagian kecil saja yang memang disiapkan menjadi ulama yang diajari bahasa Arab dan karya-karya klasik abad pertengahan. ${ }^{27}$

Perkembangan lain yang penting saat Abdul Wahid Hasyim melakukan pembaruan di Madrasah Nizamiyah ialah mulai diperkenalkannya kursus-kursus pidato, bahasa Belanda, Inggris dan mengetik. Jumlah santri menjadi banyak, mulai dengan 28 orang santri di tahun 1899, menjadi lebih dari 200 orang menjelang akhir 1910-an; dan 10 tahun berikutnya melonjak hampir mencapai 2.000 orang. Kompleks pondok baru dibuat di Seblak di tahun 1923 yang jauhnya kurang lebih 150 M dari Tebuireng. Pesantren Seblak kini menjadi Pesantren Putri.28

Abdul Wahid Hasyim, berpandangan bahwa Pendidikan Islam harus bebas dari kungkungan fanatisme. Dia menyatakan pada pidatonya saat pembukaan Perguruan Tinggi Agama Islam Negeri di Jogjakarta tahun 1951.

"Sebenarnya pengetahuan tidak boleh dikungkung oleh perasaan keagamaan yang sempit. Tiap-tiap muslim sejati, sebagai orang demokrat memandang pengetahuan dari sudut logika semata-mata; perasaan dan batin dalam lapangan mencari pengetahuan dan mengadu kebenaran, harus dikesampingkan." 29

Dengan Pendidikan Islam yang demokratis, Abdul Wahid Hasyim ingin memberikan sikap yang objektif terhadap agama (Islam). Karena bila Pendidikan Agama (Islam) disikapi dengan cara yang sempit maka akibatnya akan terjadi fanatisme yang berlebihan. Disamping pemikirannya mengenai pendidikan Islam yang demokratis, Abdul Wahid Hasyim juga berpendapat bahwa Pendidikan Islam juga harus bebas dari bayang-bayang politik. Bukan saja pengetahuan harus bebas dari kungkungan perasaan yang sempit, tetapi ilmu harus bebas dari pertimbangan-pertimbangan politik. Angkatan pertama dari ummat Islam dahulu

70 persen dari keseluruhan kurikulum. Lihat Achmad Zaini, K.H. Abdul Wahid Hasyim Pembaru Pendidikan Islam (Jombang: Pesantren Tebuireng, 2011), 37.

27 Zaini, K.H. Abdul Wahid Hasyim Pembaru Pendidikan Islam, 37.

28 Zamakhsyari Dhofier, Tradisi Pesantren Studi Pandangan Hidup Kyai dan Visinya Mengenai Masa Depan Indonesia (Jakarta: LP3ES, 2011), 178.

${ }^{29}$ Atjeh, Sedjarah K.H.A. Wahid Hasjim dan Karangan Tersiar, 813.

Jurnal Pendidikan Agama Islam

Volume 4 Nomor 2 Nopember 2016

ISSN(p) 2089-1946\& ISSN(e) 2527-4511

Hal. 324 - 336 
kala, tidak menundukkan ilmu pengatahuan pada politik, tetapi sebaliknya menundukkan politik pada ilmu." 30

Dalam pemikiran Pendidikan Islam, Abdul Wahid Hasyim mengajarkan sikap toleransi ini, dia ungkapkan dalam tulisannya yang berjudul "Nabi Muhammad dan Persaudaraan Islam";

“... Bukankah Nabi Muhammad S.A.W. itu yang menegakkan pengakuan pada Nabi Isa A.S. sebagai pesuruh (Rasul. Pen) Allah? Oleh karena itu orang yang hidup di zaman Beliau yaitu orang Yahudi, Nabi Isa bin Maryam A.S. itu digambarkan sebagai orang yang jahat, berkelakuan buruk dan dari keturunan yang tidak baik. Tapi Nabi Muhammad S.A.W. Beliau diakui sebagai pesuruh (Rasul. Pen) Allah yang mulia. Walaupun pada waktu itu kepentingan umat Islam dan penganutpenganut Nabi Isa bin Maryam A.S. bertentangan, tetapi Nabi Muhammad S.A.W. tidak kehilangan pertimbangan yang adil, dan mengakui kebenaran sebagai hakikat yang harus dipertahankan."31

Selain itu, menurut Abdul Wahid Hasyim, dengan sikap ini orang menjadi begitu terbuka, dalam arti orang menjadi tidak terbebani perasaan dan pikirannya akan perbedaan yang ditemui, bahkan tak jarang kedua pihak yang saling berbeda akan senantiasa bekerjasama, asal tidak menyangkut masalah-masalah keagamaan yang dianggap prinsipil. Sejarah telah membuktikan, menurut Abdul Wahid Hasyim, meskipun Khalifah Harun al-Rasyid maupun Khalifah al-Ma'mun adalah seorang raja yang beragama Islam taat, namun dalam hal penggunaan tenaga ahli, para Khalifah tersebut merasa tak terhalangi untuk menggunakan tenaga ahli yang beragama Nasrani:

“... Orang yang mempelajari Khalifah Harun Rasyid (lahir pada tahun 763 dan meninggal tahun 809 Masehi) pasti mengetahui, bahwa dokter kesehatannya adalah seseorang yang beragama masehi, dan bahwa kepala gedung perpustakaan Khalifah Ma'mun (lahir pada tahun 786 dan meninggal pada tahun 833), juga seorang Nasrani. Banyak sekali kedudukan-kedudukan yang penting diserahkan pada orang-orang di luar kelangan muslimin." 32

Dengan begitu, pendidikan Islam mengembangkan sikap toleran kepada siapa saja. Artinya umat Islam senantiasa dididik untuk menjadi umat yang benarbenar menghargai dan menghormati sebuah perbedaan yang terjadi, bahkan bila perlu saling bekerjasama asal tidak sampai mengganggu nilai-nilai keberagamaan secara prinsipil. ${ }^{33}$

Abdul Wahid Hasyim selama menjabat menteri Agama, juga berinisiatif untuk mengembangkan sistem Pendidikan Islam yang sudah ada, misalnya,

\footnotetext{
${ }^{30}$ Atjeh, Sedjarah K.H.A. Wahid Hasjim dan Karangan Tersiar, 814.

${ }^{31}$ Atjeh, Sedjarah K.H.A. Wahid Hasjim dan Karangan Tersiar, 677-679.

${ }^{32}$ Atjeh, Sedjarah K.H.A. Wahid Hasjim dan Karangan Tersiar, 679.

33 Arif, K.H. Abdul Wahid Hasyim (1914-1953). Wawasan Keislaman dan Kebangsaan, 59-61.
} 
mendirikan PGA (Pendidikan Guru Agama) dan PTAIN (Perguruan Tinggi Agama Islam). K.H. Abdul Wahid Hasyim menyadari bahwa kebanyakan guru yang mengajar di madrasah adalah lulusan HIS atau hanya lulusan pesantren yang dianggap belum mampu mengemban tugas tersebut, oleh karena itu berdirinya PGA di setiap provinsi dan kemudian tiap kabupaten mempunyai arti yang sangat penting. Sehingga guru-guru madrasah yang lulusan PGA dilengkapi dengan berbagai keterampilan proses belajar mengajar yang modern. Hal ini mempunyai dampak positif dalam membantu peningkatan kualitas lulusan madrasah.

Wahid Hasyim juga mendirikan PTAIN (Perguruan Tinggi Agama Islam Negeri) pada tanggal 26 Desember 1951 di Jogjakarta, yang kemudian berkembang menjadi 14 IAIN, satu IAIN di tiap 14 Provinsi, menampung kurang lebih tiga puluh ribu mahasiswa. Perkembangan IAIN masa tersebut sangat bergantung pada perkembangan madrasah dan PGA, karena IAIN adalah Perguruan Tinggi yang calon mahasiswanya mayoritas berasal dari madrasah ataupun PGA. Pendirian Perguruan Tinggi tersebut untuk mencapai kemajuan dengan memberikan penekanan pada pengembangan atmosfir berpikir secara rasional. Tujuan Wahid Hasyim mendirikan dan mengembangkan madrasah adalah dalam rangka mengkompromikan dan menjembatani dua sistem, sistem Barat dan Pesantren (Pendidikan Islam). Melihat upaya Wahid Hasyim tersebut, Zaini berargumen bahwa jelaslah dia (K.H. Abdul Wahid Hasyim) telah berhasil menjadikan Departemen Agama sebagai jembatan antara tradisi pesantren dengan peradaban modern.

\section{Demokratisasi Pendidikan Islam Menurut KH. Abdul Wahid Hasyim}

Dalam artikel berjudul "Abdullah Ubaid sebagai Pendidik", Rifai menjelaskan,34 performance Abdul Wahid Hasyim menunjukkan bahwa dirinya adalah seorang pendidik yang humanis. Pendekatan kemerdekaan dan kebebasan bagi yang dididik tidak lagi ditempatkan sebagai objek, tetapi subjek, guru dan murid juga sama-sama belajar. Bukan hanya itu, Abdul Wahid Hasyim mengungkapkan bagaimana pentingnya menanamkan sikap percaya diri, dan mandiri.

Di sisi lain, K.H. Abdul Wahid Hasyim menjelaskan betapa pentingnya menanamkan sikap percaya diri:

“... kami kemukakan sedikit pengetahuan dan pengalaman kami tentang pendidikan yang menuju kepada kepercayaan kepada tenaga dan kekuatan diri sendiri itu. Kami mengetahui seseorang yang tidak perlu kami sebutkan namanya di sini, cukup sebut si A saja supaya mudah. Si A ini mendidik anaknya, dengan suatu kebiasaan, yaitu apabila sianak terjatuh dan menangis, maka tidaklah sekali-

34 Rifai, Wahid Hasyim (Yogyakarta: Garasi, 2009), 117.

Jurnal Pendidikan Agama Islam

Volume 4 Nomor 2 Nopember 2016

ISSN(p) 2089-1946\& ISSN(e) 2527-4511

Hal. 326 - 336 
kali anak tersebut ditolongnya, tetapi memanggil, disuruh berdiri sendiri dan diperintah supaya berjalan mendatangi si A. Sudah tentu pada mula-mula kali (awalnya. pen) anak yang terjatuh itu tidak suka, tetapi karena dibiarkan saja, maka sianak itu terpakasa berdiri sendiri, berjalan mendatangi bapaknya. Beberapa lamanya kemudiian tampak benar kebaikan pendidikan si A pada anaknya itu, yaitu misalnya jika anak itu jatuh, tidaklah anak itu menangis sebagai kebiasaan anak-anak lain, akan tetapi diam saja merasakan kesakitannya akibat jatuh itu, kemudian sebentar lalu berdiri dan berlari seakan-akan tidak terjadi padanya suatu apa-apa."35

Dalam tulisan ini juga K.H. Abdul Wahid Hasyim semakin menekankan betapa pentingnya menanamkan sikap percaya diri dan mandiri dengan cara mengungkapkan pendidikan keluarga yang ada di Inggris. Dalam buku A. Athiatullah yang berjudul London, menerangkan bahwa kebiasaan orang di negeri Inggris apabila anak-anak mereka menginjak dewasa, mereka diberikan kamar tersendiri beserta perabotan yang ada di dalamnya, seperti lampu, meja kursi, tempat tidur dan lain sebagainya. Anak tersebut diberikan uang jajan bukan setiap hari melainkan seminggu sekali. Maka anak tersebut harus mengatur bagaimana uang jajan tersebut bisa cukup sampai tujuh hari dan tidak kurang. Bila uang jajannya tersebut tidak cukup memenuhi kebutuhannya sampai tujuh hari, maka itu adalah resiko yang harus ditanggungnya. Kalaupun uang jajan tersebut lebih anak tersebut bisa menyimpannya dalam tabungan.

Anak tersebut bukan hanya harus bisa mengatur uang jajannya sendiri, juga anak tersebut harus bisa mengatur bagaimana kamarnya bisa bersih dan tertata rapi. Anak tersebut diberikan otoritas penuh terhadap kamarnya, bila Bapaknya ingin masuk ke kamar anaknya, maka dia harus mengetuk pintu. Jika si anak tidak mengizinkan Bapak untuk masuk, maka ini adalah suatu konsekuensi. Dalam hal ini K.H. Abdul Wahid Hasyim mengungkapkan:

"Apakah buah pendidikan yang diusahakan demikian itu? Buahnya adalah si anak yang terdidik dengan cara itu, kira-kiran berumur 10 tahun sudah dapat mempraktikkan mengurus rumah tangga kecil dengan sekalian soal-soal (perkara) yang berhubungan dengan rumah tangga. Kelak di belakang hari, apabila anakanak itu berumah tangga, tidak lagi menjadi tanggung. Ini akibat juga langsung dari pendidikan pekerti, yaitu anak tadi adalah biasa dapat menyelenggarakan dirinya sendiri (mandiri. pen). Tidak selalu bergantung kepada ibu bapak." 36

Dalam data lain, tulisan K.H. Abdul Wahid Hasyim yang berjudul Kemajuan Bahasa, Berarti Kemajuan Bangsa. Dia mencermati pentingnya kemajuan bahasa, apalagi waktu itu usia Indonesia masih belia. Kemajuan bahasa Indonesia bagi K.H. Abdul Wahid Hasyim merupakan salah satu hal yang dapat memperkuat karakter

\footnotetext{
${ }^{35}$ Atjeh, Sedjarah K.H.A. Wahid Hasjim dan Karangan Tersiar, 793.

36 Ibid., 795.
} 
Moh. Ismail

bangsa. Tidak hanya bangsa Indonesia, namun semua negara di dunia juga memperlihatkan bagaimana bahasa menunjukkan kekuatan sebuah bangsa. ${ }^{37}$

Rifai, menjelaskan K.H. Abdul Wahid Hasyim mengkhawatirkan gejala banyak anak muda dan beberapa pemimpin yang suka memakai bahasa asing dari pada bahasanya sendiri yakni bahasa Indonesia dalam setiap pertemuan, resmi maupun tidak resmi. Seperti yang jelaskan K.H. Abdul Wahid Hasyim berikut ini:

"Bagi orang yang berdiam di kota atau yang acapkali berkunjung ke kota, niscaya akan membenarkan perkataan penulis ini. Bukankah kerap kali benar, ia bahkan boleh dikata saban pagi sebagian dari kaum muda kita, yang oleh kita, kita beri gelar "harapan bangsa, angkatan baru, bunga tanah air, dan lain sebagainya. itu yang sebagian banyak senang mengucapkan kalimat Good Morning atau Goeden Margen dan entah Good apa lagi, daripada melafadkan Selamat Pagi. Teristimewa kalau bertemu dengan seorang kawannya, seolah-olah berat, tak kuasa dan bagaikan kelu lidahnya manakala ditegur dengan Apa Kabar? Sedang wajahnya membayang muram; tetapi bilamana ditegur How Do You Do? Atau Hoe Maak Je't? Riangnya bukan main dan seketika itu juga dijawab dengan lancar dan fasih, seakan-akan tiada merasa berat dan kemalasannya hilang seketika! (ganjil bukan?). Nah sekianlah perbedaan bahasa kita dengan bahasa asing itu. Hanyalah sebagai bukti bahwasanya kemajuan bangsa itu berarti kemajuan bangsa, dan bukanlah keterangan penulis yang demikian itu penuh berkehendak merendahkan pada mereka yang tergila-gila barat itu bukan, pun bukanlah berarti bahwasanya penulis benci atau tiada setuju dengan orang yang berbahasa asing itu sekali-kali bukan. Penulis senang kepada orang belajar bahasa asing dan setuju juga, kecuali termasuk kewajiban sebagai putera Timur yang muslim, yang diharuskan menuntut akan sekalian kepandaian yang ada diatas dan ilmu pengetahuan yang beraneka ragam itu, pun penulis pernah juga belajar sekalipun hanya satu One dua One atau se-Een dua Een, tetapi dalam selama kita belajar itu, kita harus tetap mempunyai anggapan dan kepercayaan bahwasanya kita putra Indonesia. Kita mempunyai bahasa sendiri, sedang kita belajar bahasa asing itu hanya sekedar untuk mengetahui belaka, tidak lain!!!..."38

Rifai, juga menegaskan bahwa Wahid Hasyim tidaklah bermaksud menghambat atau menghalangi seseorang untuk belajar dan menyukai berbagai bahasa asing. Penguasaan bahasa asing merupakan hal yang penting tetapi jangan sampai melupakan bahasa Indonesia karena penggunaan bahasa Indonesia dalam kehidupan sehari-hari merupakan bentuk penguatan karakter sebuah bangsa yang masih muda seperti Indonesia. ${ }^{39}$

KH. Abdul Wahid Hasyim berpendapat bahwa bahasa sebagai salah satu elemen penting dalam perkembangan kemajuan pendidikan Indonesia. Dia mendukung sepenuhnya bagi proses penerjemahan karya-karya bahasa asing

\footnotetext{
${ }^{37}$ Rifai, Wahid Hasyim, 119.

${ }^{38}$ Atjeh, Sedjarah K.H.A. Wahid Hasjim dan Karangan Tersiar, 798.

${ }^{39}$ Rifai, Wahid Hasyim, 120.
}

Jurnal Pendidikan Agama Islam

Volume 4 Nomor 2 Nopember 2016

ISSN(p) 2089-1946\& ISSN(e) 2527-4511

Hal. 328 - 336 
kedalam bahasa Indonesia. Hal itu dibuktikannya dalam memberikan kata pengantar dalam buku terjemahan hadits shahih Bukhari tahun 1953 yang berjudul Pentingnya Terjemahan Hadith Pada Masa Pembangunan.

Dalam sambutan tersebut KH. Abdul Wahid Hasyim menjelaskan, bahwa kesalahpahaman yang berbau serba Arab itu identik dengan Islam. Mereka masih belum bisa membedakan mana tradisi Arab yang itu memang milik Arab dengan ajaran Islam sehingga mereka mencampuradukkan keduanya menjadi satu, semuanya yang berbau Arab pasti Islam.

"Sebenarnya ke-Islaman dan ke-Araban adalah dua hal yang berpisahan, masingmasing berdiri sendiri. Akan tetapi karena salah memahamkan soal tersebut, lalu menimbulkan pendapat yang mencampuradukkan antara ke-Islaman dan keAraban; suatu pendapat yang perlu diperbaiki. Apalagi jika diingat, bahwa keAraban dalam hal ini, adalah ke-Araban dalam gambarannya yang lama; sedang ke-Araban yang modern pada waktu ini masih belum dimasukkan orang ke Indonesia. Pada akibatnya kesalahan memahami perbedaan antara ke-Islaman dan ke-Araban itu, jika dipikirkan dengan tenang dan teliti, adalah suatu langkah yang tidak sewajarnya...". ${ }^{40}$

KH. Abdul Wahid Hasyim juga memberikan kontribusi pemikiran pada Filsafat Pendidikan melalui amanatnya dalam konfrensi Pendidikan Agama bulan Desember 1950 di Jogjakarta. ${ }^{41}$ Amanat tersebut dia tuangkan dalam tulisan yang berjudul Pendidikan Ketuhanan. Rifai menjelaskan bahwa pilihan pendidikan ketuhanan bagi K.H. Abdul Wahid Hasyim dirasa penting karena dasar negara bangsa atau perjuangan kemerdekaan kita juga berdasarkan nilai ketuhanan. Nilai-nilai ketuhanan perlu ditanamankan sebagai nilai pendidikan tidak menjadi semangat materialis, tetapi bernilai bagi kehidupan berbangsa dan bernegara yang lebih mulia dan bermartabat.

Bagi KH. Abdul Wahid Hasyim, manusia Indonesia baru dalam garis besarnya terbagi menjadi dua golongan yang kedua-duanya tidak sehat:

"Segolongan ialah orang yang maghrur (arrogant), menyangka dirinya maha tahu. Golongan ini tidak terbatas pada yang belajar menurut cara Barat, tetapi juga pada mereka yang mendapat pelajaran menurut cara Timur. Mereka dinamakan maghrur atau arrogant oleh karena mereka tidak tahu menahu tentang falsafah lawannya. Hanya menetapkan dengan cara membeo pada orang lain. Bahwa pendiriannya adalah lebih baik daripada pendirian lawannya. Segolongan orang maghrur (inferieou), merasakan dirinya kurang dari orang lain. Ghurur (arrogansi) dan syu'ur bil-qahri (inferioriteit) adalah akibat daripada pengertian yang kurang dalam. Yang pertama membawa kesudahan bekerja tidak beraturan dan secara serampangan dan yang kedua membawa kesudahan diam tidak berani bertindak, atau bertindak tetapi dengan cara ragu-ragu. Kedua-duanya adalah

\footnotetext{
40 Atjeh, Sedjarah K.H.A. Wahid Hasjim dan Karangan Tersiar, 823.

${ }^{41}$ Atjeh, Sedjarah K.H.A. Wahid Hasjim dan Karangan Tersiar, 80.
} 
akibat kemalasan yang jelek, bukan malas bekerja, tetapi malas yang lebih dalam lagi, yaitu malas berfikir, suatu hal yang terdapat pada kebanyakan bangsa kita yang harus dirubah dan tinggalkan. ${ }^{42}$

Dalam pemikiran pendidikannya, KH. Abdul Wahid Hasyim juga menanamkan nilai toleransi antar umat beragama untuk kemajuan bangsa, hal ini tertuang pada pidatonya saat menyambut berdirinya Universitas Islam Sumatera Utara di Medan 1952, yang berjudul Perguruan Tinggi Islam.

“... jalan pengetahuan dan bukan lainnya, adalah jalan yang benar-benar menuju kemajuan dan kebahagiaan itu. Memang jalan pengetahuan kearah kemajuan dan kebahagiaan menghendaki keuletan, kesabaran dan waktu yang lama, tidak dapat dipercepat atau di 'revolusi'-kan seperti jalan politik umpamanya. Akan tetapi jalan pengetahuan itu benar-benar menuju kepada kemajuan dan kebahagiaan, tiada ada kemungkinannya menyesatkan seperti jalan-jalan yang lain.... Suatu hal yang menggembirakan di dalam pembukaan Perguruan Tinggi Islam ini perlu saya catat disini, bahwa walaupun Perguruan Tinggi ini memakai nama suatu agama tertentu, yaitu Islam, diantara tenaga-tenaga yang memajukannya, baik di kalangan pengajar maupun di kalangan pengajarnya, terdapat orang-orang dari macam-macam golongan agama. Kiranya ini suatu permulaan yang baik bagi kebebasan pikiran dari ikatan-ikatan perasaan yang timbul karena perbedaan kepercayaan dan agama. Maka patutlah dikemukakan harapan disini, bahwa perasaan harga-menghargai dan kerjasama yang baik itu, dapat dipelihara selanjutnya. Bukan saja dalam batas lingkungan Perguruan Tinggi Islam ini, akan tetapi kiranya dapat pula disebarluaskan keluar dan diisikan kepada pelajarpelajar dan siswa-siswa untuk mereka itu, khususnya dan untuk generasi yang akan datang umumnya. Disini patut dikemukakan anjuran dan penghargaan yang keras kepada para mahasiswa, kiranya sukalah saudara-saudara mencurahkan segala tenaga, untuk menjadi pendukung cita-cita tersebut, dengan mengikuti segala kuliah, mempelajari buku-buku sumber pengetahuan (literatur) dengan segala susah payah, karena susah payah adalah pangkal segala hasil. " 43

Pada tulisannya yang berjudul Tuntutan Berfikir, Rifai menjelaskan tertuang pemikiran pendidikan KH. Abdul Wahid Hasyim bahwa pendidikan sebagai jembatan orang menjadi bermartabat. Jembatan tersebut membuat orang mau berubah dari bodoh kemudian belajar sehingga menjadi pintar; dan orang miskin menjadi mengerti jika kemiskinan yang dialaminya dapat berubah jika ia mau berfikir, kemudian dapat mencari pekerjaan sehingga dapat lepas dari jerat kemiskinan; dari orang yang terjajah ia kemudian mengerti kalau dijajah itu tidak enak kemudian berjuang untuk merdeka. ${ }^{44}$

KH. Abdul Wahid Hasyim, juga menjelaskan bahwa Islam mengajarkan berfikir secara demokratis. Kiai Wahid berpendapat bahwa Islam mengajari

\footnotetext{
42 Atjeh, Sedjarah K.H.A. Wahid Hasjim dan Karangan Tersiar, 804.

${ }^{43}$ Atjeh, Sedjarah K.H.A. Wahid Hasjim dan Karangan Tersiar, 808-809.

${ }^{44}$ Rifai, Wahid Hasyim, 124.
}

Jurnal Pendidikan Agama Islam

Volume 4 Nomor 2 Nopember 2016

ISSN(p) 2089-1946\& ISSN(e) 2527-4511

Hal. 330 - 336 
berpikir secara demokratis dengan menggunakan logika dan mantik, sehingga dalam al-Quran sendiri banyak dimuat kritik-kritik orang pada Nabi Muhammad SAW. ${ }^{45}$ Mereka mengatakan bahwa Nabi Muhammad adalah gila. Tujuannya untuk menunjukkan kepada kaum muslimin bahwa di antara manusia ada yang bersikap lancang, setelahnya kehabisan dalil dan alasan waktu bermusyawarah dan berunding. Lalu mengeluarkan maki-makian dan kata-kata kotor. Selain itu, dengan dimuatnya ucapan-ucapan lawan Nabi Muhammad yang kotor itu, di dalam al-Quran, dimaksudkan untuk memberikan pelajaran bahwa makianmakian demikian tidak akan merugikan, kecuali pada orang yang mengeluarkan sendiri.

\section{Relevansi Pemikiran KH. Wahid Hasyim tentang Demokrasi Pendidikan Islam dengan Pendidikan Masa Kini}

Dengan semangat memajukan pesantren, Wahid Hasyim memadukan pola pengajaran pesantren yang menitikberatkan pada ajaran agama dengan pelajaran ilmu umum. Sistem klasikal diubah menjadi sistem tutorial. Selain pelajaran Bahasa Arab, murid juga diajari Bahasa Inggris dan Belanda. Dengan semangat modernitas seperti ini beliau memberi nama lembaga yang didirikannya dengan nama madrasah nidzamiyah. ${ }^{46}$ Nama lembaga ini diambil dari madrasah di dinasti turki usmani pada masa lampau.

Dengan demikian Wahid Hasyim merupakan orang yang pertama kali memoderniskan pesantren dengan cara memasukkan pelajaran umum kedalam kurikulum di pesantren yang pada saat itu materi agama diberikan dengan porsi yang penuh. Beliau mempunyai pemikiran seperti ini karena menganggap bahwa seorang santri ketika sudah lulus di dunia pendidikan pesantren harus bisa diterima di masyarakat. Karena di masyarakat, penggunaan ilmu pengetahuan umum sangat penting karena sesuai dengan kebutuhan dan karakternya memang ilmu dunia, bukan ilmu agama yang mempunyai orientasi akhirat.

Dewasa ini, umat Islam dihadapkan pada era globalisasi yang disinyalir telah membawa dampak luar biasa terhadap peradaban manusia, termasuk melanda dunia pendidikan Islam. Bahkan globalisasi pula yang menyebabkan manusia menjadi lupa daratan, manusia tercerabut oleh posisinya sendiri sebagai manusia yang memiliki harkat dan martabat tinggi. Adanya globalisasi

\footnotetext{
${ }^{45}$ Atjeh, Sedjarah K.H.A. Wahid Hasjim dan Karangan Tersiar, 75.

46 Pada tahun 1935 ia mulai membuka madrasah modern, dengan nama Madrasah Nizamiyah. Semua kritik tak ia hiraukan, namun dengan berjalannya waktu percobaan madrasah modern itu melahirkan hasil yang baik, murid-murid pandai berbahasa Arab, juga lancar bahasa Belanda dan Inggris. Banyak orang kagum dan percaya, yang akhirnya banyak yang mendaftarkan anaknya untuk belajar di sekolah itu.
} 
yang dibarengi dengan majunya ilmu pengetahuan dan teknologi memberikan kemudahan bagi masyarakat luas dalam segala hal.

Kecenderungan inilah yang harus diantisipasi oleh dunia pendidikan Islam jika ingin menempatkan pendidikan Islam sebagai agen pembangunan dan perkembangan yang tidak ketinggalan zaman. Untuk itu pendidikan Islam dituntut harus bisa mempersiapkan sumber daya manusia yang adaptif, mampu menerima serta mampu menyesuaikan dengan arus perubahan yang terjadi dalam lingkungannya. ${ }^{47}$ Dalam menjawab tantangan globalisasi dan industrialisai tugas pendidikan tidak hanya transfer of knowledge, tetapi bagaimana pendidikan mampu memberikan konsep yang mapan dalam melihat realitas yang terjamin. Tugas tersebut nampaknya belum sepenuhnya dilaksanakan oleh masyarakat muslim pada masa sekarang ini. Bahkan masyarakat muslim cenderung menutup diri. Akibatnya mau tak mau harus ketinggalan laju kereta yang jauh dalam hal ilmu pengetahuan dan teknologi.

Hal ini bisa dilihat dari proses pendidikan Islam yang ada saat ini, yang mana sampai saat ini masih ada anggapan bahwa pendidikan Islam itu identik dengan kejumudan, kemandegan dan kemunduran. ${ }^{48}$ Kesan ini didasarkan pada kenyataan bahwa dewasa ini mayoritas umat Islam hidup di negara-negara dunia ketiga dalam serba keterbelakangan ekonomi dan pendidikan. ${ }^{49}$ Akibatnya umat Islam selalu termarginalisai dan selalu didikte oleh hegemoni barat sehingga umat Islam kehilangan jati diri dan penghargaan diri.

Melihat realitas yang demikian itu, sudah selayaknya umat Islam harus melakukan upaya aktualisasi, kontekstualisasi dan formulasi teologi agar teologi tersebut selalu aktual dan relevan dengan tingkat perkembangan historisitas pemikiran manusia sebagaimana yang pernah berkembang pada masa keemasaan Islam. Agar teologi tersebut tetap aktual sepanjang zaman, menurut Wahid Hasyim, teologi harus bisa memberi kesempatan kepada semua orang untuk ikut berpartisipasi dalam penafsiran ajaran agama secara berbeda sesuai kapasitas intelektual masing-masing dan kondisi sosial yang ada.

Untuk itulah harus ada perubahan paradigma baru dalam pelaksanaan pendidikan Islam agar dapat mengejar ketertinggalannya. Adanya perubahan paradigma ini bukannya menganggap bahwa paradigma yang lama itu jelek, akan tetapi paradigma baru digunakan untuk merevisi paradigma yang

47 Yusuf Amir Feisal, Reorientasi Pendidikan Islam (Jakarta : Gema Insani Pres, 1995), 131.

48 Abdurrahman Mas'ud, Menggagas Format Pendidikan Nondikotomik; Humanisme Religius Sebagai Paradigma Pendidikan Islam (Yogyakarta : Gama Media, 2002), 1.

${ }^{49}$ Mas'ud, Menggagas Format Pendidikan Nondikotomik, 1.

Jurnal Pendidikan Agama Islam

Volume 4 Nomor 2 Nopember 2016

ISSN(p) 2089-1946\& ISSN(e) 2527-4511

Hal. 332 - 336 
sudah ada yang kiranya sudah tidak sesuai dengan perkembangan dan perubahan zaman.

Satu hal yang harus diingat oleh umat Islam adalah, mengapa dunia barat mengalami kemajuan yang begitu luar biasa, padahal sebelumnya mereka tertinggal jauh dengan umat Islam? Hal ini tentunya dikarenakan adanya pergeseran paradigma di dunia barat. Bagaimana mereka mampu melakukan perubahan luar biasa terhadap hegemoni agama dan berani keluar dari kungkungan agama tersebut. Bagi mereka, agama hanya akan menghambat majunya ilmu pengetahuan yang selama ini mereka pelajari, karena itulah mereka menentang hegemoni agama terhadap kehidupannnya.

Tampaknya dalam Islam belum terjadi pergeseran paradigma sebagaimana yang terjadi di dunia barat. Hal ini bisa dilhat dengan adanya fakta bahwa pemikiran Islam yang mendominasi dan menjadi mainstream umat Islam hingga abad ke-21 ini adalah produk instant dari zaman klasik.50 Tidak ada inovasi-inovasi baru dalam pemikiran pendidikan Islam yang dapat membawa perubahan dan perkembangan.

Belum terjadinya pergeseran paradigma tersebut menarik untuk disimak mengingat dua hal. ${ }^{51}$ Pertama, bila dicermati, realitas umat Islam saat ini jauh berbeda dengan realitas umat Islam zaman ketika formulasi pemikiran Islam klasik tersebut dirumuskan. Hal ini seharusnya mendorong adanya paradigma baru, karena umat Islam mengalami perkembanagan intelektualitas dan juga menghadapi perubahan yang sejalan dengan sifat perubahan dan perkembanagan dari kehidupan manusia itu sendiri. ${ }^{52}$

Hal tersebut akan memberikan peluang bagi semua orang di semua zaman untuk terlibat langsung dan bersentuhan serta berdialog langsung dengan teks suci ajaran agama. Yang akhirnya akan membangkitkan partisispasi masyarakat luas terhadap aktifitas keagamaan. Dalam posisi manusia yang demikian inilah wahyu al-Quran menjadi paradigma perubahan dan perkembangan pemahaman yang kemudian melahirkan kebudayaan. Oleh karena itu suatu kemustahilan logis jika seseorang menyatakan bahwa pendapat mengenai pemahamannya atas wahyu telah mencapai kebenaran yang pasti.

Dengan pemahaman yang demikian maka menjadi sangat mungkin bagi generasi Islam saat ini untuk melakukan rekonstruksi terhadap

\footnotetext{
50 Agus Nuryatno, Islam, Teologi Pembebasan, dan Kesetaraan Gender; Studi atas Pemikiran Asghar Ali Engineer (Yogyakarta : UII Press, 2001), IX.

${ }^{51}$ Nuryatno, Islam, Teologi Pembebasan, dan Kesetaraan Gender, X.

52 Nuryatno, Islam, Teologi Pembebasan, dan Kesetaraan Gender, 25-26.
} 
pemikiran klasik dengan pemikiran yang baru, segar dan dinamis yang mampu berhadapan dan berdialog dengan persoalan-persoalan kontemporer dewasa ini. Hal ini sesuai dengan salah satu ajaran Islam yang telah disampaikan Nabi Muhammad SAW, yaitu intelektualisasi total, suatu proses penyadaran kepada umat dalam belbagai dimensi keagamaan baik itu mauidhah hasanah, ceramah hikmah dan lain sebagainya.

Dalam dimensi kultural, Nabi mengajarkan umat agar bebasdari tradisi taqlid buta. Yakni meniru adat nenek moyang tanpa menggunakan akal kritisnya. Disini Rosul mengajarkan tradisi baru yang berupa Sunnah Rasul. Dalam tradisi baru ini Rasul mengajarkan akal sebagai inti keberagmaan seseorang. Selain tunduk kepada ajaran al-Qur'an dan hadits, umat muslim harus mempertimbangkan akal atau rasionya. Dalam Islam mempertahankan akal, harta benda, keluarga, martabat, nyawa, dan agama adalah suatu keharusan bagi setiap individu. Ajaran Nabi; "La dina liman la aqlah " (tidaklah beragama orang yang tidak menggunakan akal pikirannya). Sehingga dengan kata lain rasio mempunyai kesejajaran dalam Islam. ${ }^{53}$

Harus diakui bahwa peradaban Islam zaman keemasan mempunyai khazanah intelektual yang luar biasa kayanya dimasa lalu. ${ }^{54}$ Realitas ini menunjukkan bahwa umat Islam pada masa lalu mempunyai semangat ijtihad (memberikan kebebasan kepada manusia untuk terlibat dan berdialog langsung dengan teks suci Al- qur'an ) yang luar biasa tinggi untuk merespon zaman dan tantangan yang mereka hadapi. ${ }^{55}$ Mereka selalu membuka diri dan tidak melulu taqlid buta terhadap para ulama' yang dianggap lebih tahu soal agama. Hal inilah yang harus kita lakukan saat ini, agar pendidikan Islam dapat menemukan kembali mutiara yang hilang sebagaimana yang pernah dialami umat Islam pada masa keemasaan, sehinggamampu berdiri sejajar dan bersaing dengan negara-negara lain.

Di tengah arus modernisasi dan globalisasi, nampaknya gagasan KH. Abdul Wahid Hasyim tentang pendidikan Islam masih sangat relevan, yang mana proses pendidikan saat ini secara dinamis harus diberi inovasi-inovasi baru sehingga tidak ketinggalan oleh perkembangan zaman dan memiliki arah dan tujuan yang jelas. Di sinilah aktualisasi dan kontektualisasi teologi diperlukan untuk merekontruksi dasar filosofis pendidikan Islam yang mampu mengarahkan proses pendidikan kepada keberhasilan yang lebih baik.

\footnotetext{
${ }^{53}$ Mas'ud, Menggagas Format Pendidikan Nondikotomik, 47,

${ }^{54}$ Nuryatno, Islam, Teologi Pembebasan dan Kesetaraan Gender, XI.

${ }^{55}$ Nuryatno, Islam, Teologi Pembebasan dan Kesetaraan Gender, XI.
} 


\section{E. Kesimpulan}

Konsep pendidikan Islam menurut KH. Abdul Wahid Hasyim, intinya terletak kepada kekebasan manusia untuk dapat terlibat dan bersentuhan secara langsung dengan teks suci ajaran agama. Dengan demikian, manusia harus diberi kebebasan untuk dapat menafsiri ajaran agama sesuai dengan batas intelektual masing-masing sesuai dengan situasi dan kondisi yang dialami oleh masing-masing manusia, sehingga mereka mampu untuk dapat mengerti dan memahami serta mengaplikasikan pemahamannya dalam kehidupan. Dalam hal relasi antara guru dan murid, yang diidekan Wahid Hasyim adalah relasi yang transformatif. Relasi transformatif adalah relasi dimana proses dialog mereka saling mengajar dan menyerap. Apa yang telah disampaikan oleh KH. Abdul Wahid Hasyim tentang pendidikan Islam masih sangat relevan bila dikaitkan dengan situasi kekinian, dimana saat ini pendidikan Islam memerlukan inovasi-inovasi untuk dapat menjawab tantangan dan ketertinggalannya. Untuk membangun pendidikan yang dapat mengembangkan fitrah manusia, maka konsep pendidikan yang ditawarkan harus beroerientasi kepada manusia, sehingga nantinya akan terjadi proses pendidikan yang humanis dan demokratis.

\section{F. Referensi}

Arif, Moch. Choirul. K.H. Abdul Wahid Hasyim (1914-1953). Wawasan Keislaman dan Kebangsaan. Tesis. Surabaya: Program Pascasarjana IAIN Sunan Ampel Surabaya, 2003.

Assegaf, Abd. Rachman. Politik Pendidikan Nasional: Pergeseran Kebijakan Pendidikan Agama Islam dari Praproklamasi ke Reformasi. Jogjakarta: Kurnia Kalam, 2005.

Atjeh, Aboebakar. Sedjarah K.H.A. Wahid Hasjim dan Karangan Tersiar. Jakarta: Panitya Buku Peringatan Alm. K.H.A. Wahid Hasjim, 1957.

Basri, Hasan. Filsafat Pendidikan Islam. Bandung: Pustaka Setia, 2009.

Darajat, Zakiah. Ilmu Pendidikan Islam. Bandung: Bumi Aksara, 2008.

Dhofier, Zamakhsyari. Tradisi Pesantren Studi Pandangan Hidup Kyai dan Visinya Mengenai Masa Depan Indonesia. Jakarta: LP3ES, 2011.

Fadeli, Soeleiman., dan Subhan, Mohammad. Buku I Antologi NU Sejarah-IstilahAmaliah-Uswah. Surabaya: Khalista, 2007.

Feisal, Yusuf Amir Feisal. Reorientasi Pendidikan Islam. Jakarta : Gema Insani Pres, 1995.

Listiana, Heni. "Dinamika Politik Pendidikan Guru Agama Islam Pada Masa Orde Lama”. Jurnal Pendidikan Agama Islam (JPAI) FTK UIN Sunan Ampel Surabaya, Vol 1, No 2 (2013). 
Moh. Ismail

Mas'ud, Abdurrahman. Menggagas Format Pendidikan Nondikotomik; Humanisme Religius Sebagai Paradigma Pendidikan Islam. Yogyakarta : Gama Media, 2002.

Marimba, Ahmad D. Pengantar Filsafat Pendidikan Islam. Bandung: al-Maarif, 1962.

Nuryanto, Agus. Islam, Teologi Pembebasan, dan Kesetaraan Gender; Studi atas Pemikiran Asghar Ali Engineer. Yogyakarta : UII Press, 2001.

Peraturan Pemerintah Republik Indonesia Nomor 19 Tahun 2005 Tentang Standar Nasional Pendidikan Bab I Ketentuan Umum Pasal 1 ayat (2).

Rahardjo, Mudjia. Pemikiran Kebijakan Pendidikan Kontemporer. Malang: UINMALIKI PRESS, 2010.

Rifai, Muhammad. Wahid Hasyim. Yogyakarta: Garasi, 2009.

Roziqin, Badiatul Roziqin. "KH. Abdul Wahid Hasyim Menjabat Menteri Agama Tiga Periode", dalam 101 Jejak Tokoh Islam Indonesia. Yogyakarta: eNusantara, 2009.

S.A.P, Rangga Sa'adillah. "Pendidikan Karakter menurut KH. Wahid Hasyim”. Jurnal Pendidikan Agama Islam (JPAI) FTK UIN Sunan Ampel Surabaya Vol. 3. No. 2 (2015).

Sanusi. K. H. A. Wahid Hasyim Mengapa Memilih NU? Konsepsi Tentang Agama, Pendidikan dan Politik. Jakarta: Inti Sarana Aksara, 1985.

Sirozi, M. Politik Pendidikan: Dinamika Hubungan antara Kepentingan Kekuasaan dan Praktik Penyelenggaraan Pendidikan. Jakarta: Raja Grafindo Persada, 2005.

SM, Ismail. Pendidikan Islam, Demokratisasi dan Masyarakat Madani. Yogyakarta : Pustaka Pelajar, 2000.

Tilaar, H.A.R. Paradigma Baru Pendidikan Nasional. Jakarta: Rineka Cipta, 2000.

Yamin, Moh. Menggugat Pendidikan Indonesia. Yogyakarta: Ar-Ruzz Media, 2009.

Zaini, Achmad. K.H. Abdul Wahid Hasyim Pembaru Pendidikan Islam. Jombang: Pesantren Tebuireng, 2011. 